\title{
Subdoses of Dicamba Herbicide on Yield Componentes in Function of the Soybean Growth Stage
}

\author{
T. Schneider ${ }^{1}$, M. A. Rizzardi ${ }^{2}$, A. P. Rockenbach ${ }^{2} \&$ S. T. Peruzzo ${ }^{2}$ \\ ${ }^{1}$ University of Cruz Alta, Cruz Alta, RS, Brazil \\ ${ }^{2}$ University of Passo Fundo, Passo Fundo, RS, Brazil \\ Correspondence: T. Schneider, University of Cruz Alta, Cruz Alta, RS, Brazil. Tel: 55-559-9948-4293. E-mail: \\ theodoroschneider@hotmail.com
}

$\begin{array}{ll}\text { Received: February 25, } 2019 & \text { Accepted: March 28, } 2019 \quad \text { Online Published: May 15, } 2019 \\ \text { doi:10.5539/jas.v11n6p407 } & \text { URL: https://doi.org/10.5539/jas.v11n6p407 }\end{array}$

\begin{abstract}
Soybean cultivars without tolerance can suffer injury from exposure to tank herbicide residues. This study aimed at assessing the potential effects of the broad spectrum herbicide dicamba on sensitive soybean during its vegetative and reproductive stages. The trial was performed in a randomized complete block design with four replications. Six rates $\left(1.4,2.8,5.6,11.2,16.8\right.$ and $\left.28.0 \mathrm{~g}^{2} \mathrm{ae} \mathrm{ha}^{-1}\right)$ of dicamba were applied at two soybean growth stages (V3 and R2). The soybeans were planted in Passo Fundo, Rio Grande do Sul state in 2015/16 agricultural year. The dicamba induced symptoms of soybean phytotoxicity showed a steady rise at all the assessment times. The soybean decreased in height as the subdose of the herbicide increased. Dicamba was observed to negatively affect the number of nodes alone, during the V3 and R2 stages. The grain yield was adversely affected at the $28.0 \mathrm{~g}$ ae ha ${ }^{-1}$ subdose, in the V3 application stage, and in response to the 16.8 and 28.0 $\mathrm{g}$ ae ha ${ }^{-1}$ subdoses in the R2 stage.
\end{abstract}

Keywords: Glycine max, tank residues, drift, soybean injury, auxin mimic herbicide

\section{Introduction}

Over the recent past various crop cultivars have been developed by the breeding agencies, they possess the herbicide resistant trait to be able to avert the presence of herbicide-resistant weeds (Vink et al., 2012). When multi resistant cultivars are made available, farmers have the option of incorporating several new weed-control management techniques, including those against glyphosate-resistant or glyphosate-tolerant weeds, while conserving the glyphosate-resistant crops (Green \& Castle, 2010; Vink et al., 2012). Roundup Ready 2 Xtend ${ }^{\circledR}$ (glyphosate- and dicamba-resistant) and EnlistTM (with resistance to glyphosate and 2,4-D) have already been made available for commercial cultivation in the United States, and are predicted for release in other countries like Brazil.

The herbicide dicamba is an auxin mimic, utilized globally for over 40 years in weed control of several dicots (Behrens et al., 2007). This herbicide disrupts cell wall plasticity and nucleic acid metabolism, stimulates the auxin response genes, causing ethylene overproduction and therefore increased abscisic acid levels (Kelley et al., 2004; Grossmann, 2010; Shaner, 2014). The abscisic acid rise results in stomatal closure and restricted $\mathrm{CO}_{2}$ assimilation, thus inhibiting plant growth (Grossmann, 2010). The commonest symptoms of the presence of auxin-mimicking herbicides in soybean are stem and leaf epithelia, stem swelling and cracking, as well as chlorosis and necrosis (Andersen et al., 2004; Kelley et al., 2005).

The introduction of dicamba-resistant soybean cultivars has unavoidably and foreseeably necessitated herbicidal spraying, which leaves behind some residues in tanks, especially near cultivars which are nonresistant to them, resulting in insults and a lowered grain yield (Olszyk et al., 2015). An 18\% drop in the grain yield was reported, caused by the residues from $1 \%$ of the commercial dose of dicamba applied to the soybean crop (Griffin et al., 2013). Under very severe circumstances, $85 \%$ yield decrease was reported in response to dicamba application in a dose of $41 \mathrm{~g}$ ai ha ${ }^{-1}$ (Johnson et al., 2012). On the contrary, soybean shows higher susceptibility to dicamba during the reproductive phase, revealing 2.5 times greater sensitivity when the application is done in the R1 than during the V3 (Griffin et al., 2013). 
Data regarding the soybean sensitivity to dicamba tank residues in the vegetative and reproductive stages under the environmental conditions of Brazil are quite scarce. Furthermore, analyses of the yield components may prove beneficial in the quantification of these effects. Exhaustive research demonstrates that the number of nodes, number of pods and grain weight are the main factors supporting high grain yields. Therefore, it becomes essential to evaluate the components influencing grain yield to clearly appreciate the way soybean exposure to auxin-mimicking herbicides impact the grain yield during the various developmental stages. A clear establishment of the effects of the dicamba residues applied on spray tanks for non-resistant soybean cultivars will enable the soy producers and pesticide applicators to understand the potential risk of injuring the soybean crop and thus reducing the soybean yield.

This study is based on the hypothesis that the soybean susceptibility to dicamba results in decreased grain yield. Therefore, this research aimed at evaluating the potential results of the dicamba herbicide on soybean, during the vegetative and reproductive growth stages.

\section{Material and Methods}

\subsection{Plant Material and Experimental Conditions}

The experiment was performed in the experimental field of the University of Passo Fundo (UPF), situated in the middle plateau region of the Rio Grande do Sul, Brazil. Located at $678 \mathrm{~m}$ altitude, with the geographical co-ordinates of $28^{\circ} 12^{\prime} 59^{\prime \prime} \mathrm{S}$ and $52^{\circ} 23^{\prime} 37^{\prime \prime} \mathrm{W}$, the soil in this experimental area is of the typical dark red variety (Embrapa, 2006). This region experiences subtropical and humid climate with hot summers classified as Cfa, according to the Köppen classification.

Prior to installing the experiment, at 20 days before sowing, glyphosate was applied across a total area of $1080 \mathrm{~g}$ ai $\mathrm{ha}^{-1}$ to the vegetation present there. Soybean, Syngenta IPRO, was planted in December 2015, maintaining $0.45 \mathrm{~m}$ line spacing with a population of 280,000 plants $^{-1} \mathrm{a}^{-1}$.

The total rainfall received during the period of the experiment was $1365.2 \mathrm{~mm}$, which is more than the climatological normal (which is $855.0 \mathrm{~mm}$ ) for this period, (Figure 1). The air temperature during this period was, on average, $21{ }^{\circ} \mathrm{C}$, falling within the climatological normal of $20.5{ }^{\circ} \mathrm{C}$ between December and April (Embrapa, 2016).

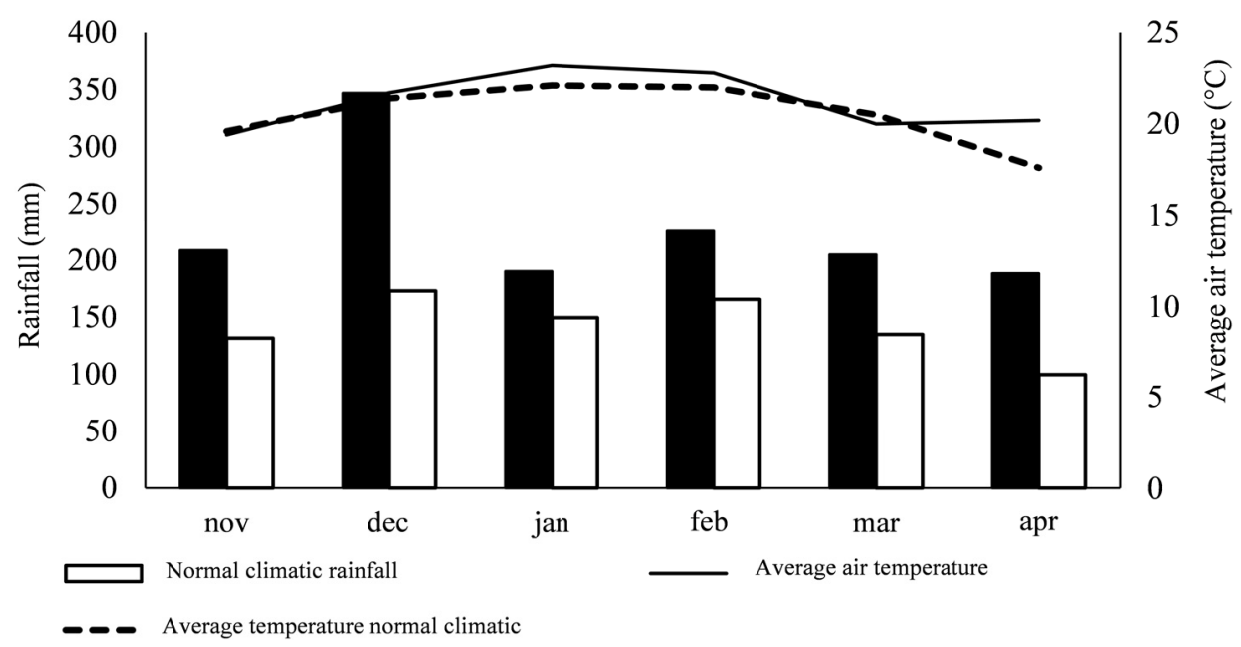

Figure 1. Rainfall monthly, normal rainfall climatic, average air temperature monthly and average air temperature normal climatic, in period of trial conduction. Passo Fundo-RS. 2016

\subsection{Experimental Design and Treatments}

The randomized block design was adopted for the experiment, arranged according to the split-plot scheme and included four replicates, each plot being $5 \mathrm{~m}$ in length and $3.5 \mathrm{~m}$ in width. The application times (stages V3 and $\mathrm{R} 2$ of soybean) were allocated for the main plot and for the subplots the dicamba (Atectra ${ }^{\circledR} 480 \mathrm{~g}$ ae $\mathrm{L}^{-1} \mathrm{BASF}$ Corporation) herbicide sub-doses were selected. The subdoses applied were: $0 ; 1.4 ; 2.8 ; 5.6 ; 11.2 ; 16.8$ and 28.0 $\mathrm{g}$ ae ha ${ }^{-1}$, respectively, representing $0 ; 0.25 ; 0.5 ; 1 ; 2 ; 3$ and $5 \%$ of the commercial dose. 


\subsection{Procedures}

Only when the soybean achieved the developmental stages specified (V3 and R2), the herbicide was added using a $\mathrm{CO}_{2}$ pressurized spray with a 110.015 fan tip, calibrated to apply the herbicide syrup at a volume of $150 \mathrm{~L} \mathrm{ha}^{-1}$. At 3, 7, 14 and 28 days post the application of the treatments (DAT), the phytotoxicity was estimated on a percentage scale, in which zero indicated the absence of symptoms and plant death, as shown in Table 1 (Frans et al., 1986; Robinson et al., 2013). At 14 and 28 DAT, the heights of ten plants within the useful plot area were measured from the main stem base to the node of the last trefoil that had emerged. During all time of the trial conductions glyphosate was applied across a total area of $1080 \mathrm{~g}$ ai ha ${ }^{-1}$ to aiming at keeping the crop free from the presence of weeds.

At the time of the harvest or maturation, 10 plants from within the useful area of each plot were recorded for plant height, number of nodes in the main stem, number of branches, total number of pods and thousand seed weight. To analyze the data, the mean values of the 10 plants evaluated were used. Also, the three central lines in the useful area of the plot were harvested using a mechanized plot harvester, and the grain yield was determined.

Table 1. Scale for visual estimate of soybean injury affected by synthetic auxin herbicides (Robinson et al., 2013)

\begin{tabular}{|c|c|}
\hline Escala & \\
\hline 0 & No injury, plant growth is normal. \\
\hline 10 & $\begin{array}{l}\text { Slight reduction in height or canomy volume, cupped or bubbled leaves on less than ore qual to the upper } 10 \% \text { of the plant, bent } \\
\text { petioles, and, chlorosis or necrosis. }\end{array}$ \\
\hline 20 & $\begin{array}{l}\text { Moderately crinkled leaflets (extended across less than or equal to the upper } 20 \% \text { of the plant), curled petioles, reduced height and } \\
\text { canopy volume, cupped terminal leaflets. }\end{array}$ \\
\hline 30 & $\begin{array}{l}\text { Moderate to high reduction of height and canopy; compacted internodes and plants begin to have an abnormal appearance; } \\
\text { malformation with drawstring, fiddleneck, or cupped effects on less than or equal to the upper } 30 \% \text { of the plant; many petioles curled } \\
\text { and main stems may be bent. }\end{array}$ \\
\hline 40 & $\begin{array}{l}\text { Highly stunted plants (less than or equal to } 40 \% \text { of the plant), petioles curled and main stems bent or starting to curl, upper leaves } \\
\text { exhibit severe malformation and expansion of new leaves suppressed, plant may have patches of necrotic tissue. }\end{array}$ \\
\hline 50 & $\begin{array}{l}\text { Very high reduction of plant height (less than or equal to } 50 \% \text { of the plant) with little likelihood of recovery from the apical } \\
\text { meristem, new growth suppressed, formation of pods reduced or malformed, some leaf and stem tissue becomes necrotic, petioles } \\
\text { and stems show severe twisting. }\end{array}$ \\
\hline 60 & $\begin{array}{l}\text { Severe height and canopy reduction, including any new growth from axillary buds; leaves severely cupped or fiddlenecked on less } \\
\text { than or equal to } 60 \% \text { of the plant; petioles and stems twisted, swollen, and splitting; more extensive die-back of tissue.. }\end{array}$ \\
\hline 70 & $\begin{array}{l}\text { Severe to very severe reduction of plants, new growth callused and inhibited, most leaves severely deformed and mostly necrotic, } \\
\text { extensive petiole bending. }\end{array}$ \\
\hline 80 & $\begin{array}{l}\text { Very severe soybean injury, less than or equal to } 80 \% \text { of the plants mainly prostrate, petioles twisted with leaves drooping, leaves } \\
\text { chlorotic or necrotic, stems severely twisted, swollen, and split. }\end{array}$ \\
\hline 90 & $\begin{array}{l}\text { Plant dying, less than or equal to } 90 \% \text { of the plants mainly prostrate, leaves and stems mostly chlorotic or necrotic, all petioles } \\
\text { severely twisted, swollen, or split. }\end{array}$ \\
\hline 100 & All plants dead. \\
\hline
\end{tabular}

\subsection{Statistical Analysis}

Data were first analyzed for normality (Shapiro Wilk test) and, later submitted to the analysis of variance ( $\mathrm{p} \leq$ 0.05). For the variables of phytotoxicity at 3, 7, 14 and 28 DAT; stature at 14, 28 DAT and at maturation, where statistical significance was observed, the Tukey test was done at $5 \%$ probability of error. For the other variables, number of nodes in the main stem, number of branches, number of pods, thousand seed weight and grain yield, in the event of statistical significance, regression analysis was performed for the factors investigated.

The regression analysis was done utilizing the Sigma Plot 10.0 program (Sigmaplot, 2007), and the data were adjusted to the sigmoidal regression equation of the logistic type, as follows: $y=a /\left[1+\left(x / x_{0}\right) b\right]$.

\section{Results and Discussion}

\subsection{Symptoms of Phytotoxicity}

Phytotoxicity symptoms caused by the dicamba herbicide in soybean were evident in response to almost all the subdoses applied. In fact, the responses became more intense throughout the evaluation period (Table 2). Three days after application of the treatments (DAT), the strongest symptoms were seen induced by the $11.20 \mathrm{~g}$ ae ha ${ }^{-1}$ subdose, achieving values of $71.2 \%$ and $15.0 \%$ for the highest subdose during the applications at V3 and R2, respectively. For 7, 14 and 28 DAT, the symptoms which were assessed were increased, becoming noticeable even at the $1.4 \mathrm{~g}$ ae ha ${ }^{-1}$ subdose, during both the V3 and R2 stages. The dicamba herbicide induced 
phytotoxicity observed in the glyphosate-resistant soybean was recorded as $21 \%$ of injury at the end of one week post application of the $3 \mathrm{~g}$ ae ha ${ }^{-1}$ and as $80 \%$ after the $41 \mathrm{~g}$ ae ha ${ }^{-1}$ applied to the soybean in its vegetative phase (Johnson et al., 2012).

Table 2. Phytotoxicity (\%) to soybean at 3, 7, 14 and 28 days after treatments applications (DAT), Syngenta 13561 IPRO cultivar, in function of dicamba subdoses and growth stages of soybean. Passo Fundo-RS, 2016

\begin{tabular}{|c|c|c|c|}
\hline \multirow{2}{*}{ Dose $\left(\mathrm{g}\right.$ ae $\left.\mathrm{ha}^{-1}\right)$} & \multicolumn{2}{|c|}{ Growth Stage } & \multirow{2}{*}{ Average } \\
\hline & V3 & $\mathrm{R} 2$ & \\
\hline \multicolumn{4}{|c|}{ Phytotoxicity at $3 \mathrm{DAT}$} \\
\hline 0.0 & $\mathrm{D}^{1} 0.0 \mathrm{a}$ & BA 20.0 a & $20.0 \mathrm{~d}$ \\
\hline 1.4 & D $30.0 \mathrm{a}$ & BA $20.0 \mathrm{~b}$ & $20.0 \mathrm{~d}$ \\
\hline 2.8 & D $32.5 \mathrm{a}$ & BA $20.0 \mathrm{~b}$ & $21.2 \mathrm{~d}$ \\
\hline 5.6 & D $32.0 \mathrm{a}$ & BA $21.2 \mathrm{a}$ & $21.6 \mathrm{~d}$ \\
\hline 11.2 & C $14.5 \mathrm{a}$ & AB $27.0 \mathrm{a}$ & $10.7 \mathrm{c}$ \\
\hline 16.8 & B $30.0 \mathrm{a}$ & AB $27.0 \mathrm{a}$ & $19.8 \mathrm{~b}$ \\
\hline 28.0 & A $71.2 \mathrm{a}$ & $\mathrm{AB} 15.0 \mathrm{~b}$ & $43.1 \mathrm{a}$ \\
\hline CV $(\%)$ & & & 9.7 \\
\hline \multicolumn{4}{|c|}{ Phytotoxicity at 7 DAT } \\
\hline 0.0 & 20.0 & 20.0 & 20.0 ee \\
\hline 1.4 & 26.5 & 20.7 & $23.6 \mathrm{de}$ \\
\hline 2.8 & 27.0 & 10.5 & $28.7 \mathrm{de}$ \\
\hline 5.6 & 10.7 & 12.0 & $11.3 \mathrm{ce}$ \\
\hline 11.2 & 17.5 & 23.2 & $20.3 \mathrm{ce}$ \\
\hline 16.8 & 27.5 & 35.5 & 31.5 be \\
\hline 28.0 & 45.0 & 52.5 & 48.7 ae \\
\hline $\mathrm{CV}(\%)$ & & & 33.6 \\
\hline \multicolumn{4}{|c|}{ Phytotoxicity at 14 DAT } \\
\hline 0.0 & DF $20.0 \mathrm{a}$ & EE $10.0 \mathrm{a}$ & $10.0 \mathrm{fc}$ \\
\hline 1.4 & DE $10.0 \mathrm{a}$ & ED $16.2 \mathrm{a}$ & $15.0 \mathrm{ec}$ \\
\hline 2.8 & $\mathrm{DE} 10.5 \mathrm{~b}$ & EC 28.7 a & $20.2 \mathrm{de}$ \\
\hline 5.6 & $\mathrm{CD} 14.7 \mathrm{~b}$ & EB $50.0 \mathrm{a}$ & $28.0 \mathrm{~cd}$ \\
\hline 11.2 & BC $23.7 \mathrm{~b}$ & EB 55.7 a & $35.6 \mathrm{bc}$ \\
\hline 16.8 & $\mathrm{AB} 32.5 \mathrm{~b}$ & $\mathrm{AB} 62.0 \mathrm{a}$ & $43.1 \mathrm{bc}$ \\
\hline 28.0 & DA $40.0 \mathrm{~b}$ & EA $69.5 \mathrm{a}$ & $52.5 \mathrm{ac}$ \\
\hline $\mathrm{CV}(\%)$ & & & 18.76 \\
\hline \multicolumn{4}{|c|}{ Phytotoxicity at 28 DAT } \\
\hline 0.0 & D $10.0 \mathrm{a}$ & $\mathrm{AE} 10.0 \mathrm{a}$ & $10.0 \mathrm{fc}$ \\
\hline 1.4 & C $16.2 \mathrm{a}$ & $\mathrm{AD} 16.2 \mathrm{a}$ & $16.2 \mathrm{ec}$ \\
\hline 2.8 & C $23.7 \mathrm{a}$ & $\mathrm{AC} 28.7 \mathrm{a}$ & $26.2 \mathrm{dc}$ \\
\hline 5.6 & B $37.2 \mathrm{~b}$ & $\mathrm{AB} 50.0 \mathrm{a}$ & $43.6 \mathrm{cc}$ \\
\hline 11.2 & B $45.7 \mathrm{a}$ & B $55.7 \mathrm{a}$ & $50.7 \mathrm{bc}$ \\
\hline 16.8 & B $45.0 \mathrm{~b}$ & $\mathrm{AB} 62.0 \mathrm{a}$ & $53.5 \mathrm{bc}$ \\
\hline 28.0 & A $65.0 \mathrm{a}$ & AA 69.5 a & $67.2 \mathrm{ac}$ \\
\hline $\mathrm{CV}(\%)$ & & & 14.95 \\
\hline
\end{tabular}

Note. ${ }^{1}$ Averages followed by the same letter high case at column and lowercase at line, do not differ by Tukey's test at $5 \%$ of error probability.

Another study stated that $40 \%$ phytotoxicity was observed in the soybean one week after the dicamba was applied in a dose of $5.6 \mathrm{~g}$ ae ha ${ }^{-1}$ and $80 \%$ with the application of the dose of $56 \mathrm{~g}$ ae ha ${ }^{-1}$ during the $\mathrm{V} 3$ growth stage (Andersen et al., 2004). During the R1 stage of the glyphosate-resistant soybean, the herbicide caused 19 and $64 \%$ phytotoxicity one week after the application of the subdoses of 1.1 and $70 \mathrm{~g}^{2} \mathrm{ha}^{-1}$ respectively, 
(Griffin et al., 2013). Usually, soybean showed susceptibility to the dicamba levels, revealing that at both the higher doses of 2,4-D at 7 and 14 DAT, the effects were dramatically more enhanced, and the soybean revealed no ability to recover until the final assessment at 28 DAT. However, when applied during the R2 stage, the symptoms became more intense, as the soybean was more vulnerable at this stage.

\subsection{Plant Height}

The dicamba herbicide dose applied induced a decrease in the stature of the soybean at all three evaluation times (14 and 28 DAT and maturation) (Table 3). Normally, the plant decreased in stature as the herbicide subdose was gradually increased. At 14 DAT, with the application being done in the V3 phase, all the subdoses induced stature reduction when compared with the control. During the R2 stage, the decrease was even more evident, especially in response to the subdoses of 5.60; 11.2; 16.80 and $28.0 \mathrm{~g}$ ae $\mathrm{ha}^{-1}$, which reduced the stature by 8,19 , 18 and $21 \%$ compared with the control.

Table 3. Plant height $(\mathrm{cm})$ of soybean at 14, 28 days after treatments applications (DAT) and at maturation, Syngenta 13561 IPRO cultivar, in function of dicamba subdoses and growth stages of soybean. Passo Fundo-RS, 2016

\begin{tabular}{|c|c|c|c|}
\hline \multirow{2}{*}{ Dose $\left(\mathrm{g}\right.$ ae $\left.\mathrm{ha}^{-1}\right)$} & \multicolumn{2}{|c|}{ Growth Stage } & \multirow{2}{*}{ Average } \\
\hline & V3 & R2 & \\
\hline \multicolumn{4}{|c|}{ Plant heigh at 14 DAT } \\
\hline 0.0 & $\mathrm{~A}^{1} 30.6^{\mathrm{ns}}$ & A $88.3^{\mathrm{ns}}$ & $59.5 \mathrm{ac}$ \\
\hline 1.4 & В 18.7 & AB 88.7 & $53.7 \mathrm{bc}$ \\
\hline 2.8 & B 18.3 & AB 84.4 & $51.3 \mathrm{bc}$ \\
\hline 5.6 & B 16.0 & BB 81.3 & $48.7 \mathrm{cc}$ \\
\hline 11.2 & В 14.6 & CB 71.4 & $43.0 \mathrm{dc}$ \\
\hline 16.8 & B 14.3 & CB 72.1 & $43.2 \mathrm{dc}$ \\
\hline 28.0 & B 14.2 & CB 69.6 & $41.9 \mathrm{dc}$ \\
\hline $\mathrm{CV}(\%)$ & & & 5.94 \\
\hline \multicolumn{4}{|c|}{ Plant heigh at $28 D A T$} \\
\hline 0.0 & $\mathrm{AD} 66.2^{\mathrm{ns}}$ & A $103.4^{\mathrm{ns}}$ & $84.8 \mathrm{a}$ \\
\hline 1.4 & BD 46.6 & A 198.0 & $72.3 \mathrm{~b}$ \\
\hline 2.8 & BD 46.9 & A 196.4 & $71.6 \mathrm{~b}$ \\
\hline 5.6 & BC 39.9 & B 185.4 & $62.6 \mathrm{c}$ \\
\hline 11.2 & CD 35.9 & C 176.0 & $56.0 \mathrm{~d}$ \\
\hline 16.8 & CD 36.6 & C 172.7 & $54.6 \mathrm{~d}$ \\
\hline 28.0 & DD 30.5 & C 172.0 & $51.2 \mathrm{~d}$ \\
\hline $\mathrm{CV}(\%)$ & & & 5.9 \\
\hline \multicolumn{4}{|c|}{ Plant heigh at Maturation } \\
\hline 0.0 & A $97.4 \mathrm{a}$ & $\mathrm{AB} 94.1 \mathrm{a}$ & $95.7 \mathrm{a}$ \\
\hline 1.4 & B $38.8 \mathrm{~b}$ & $\mathrm{AB} 93.6 \mathrm{a}$ & $66.2 \mathrm{~b}$ \\
\hline 2.8 & B $40.4 \mathrm{~b}$ & $\mathrm{AB} 87.7 \mathrm{a}$ & $64.0 \mathrm{~b}$ \\
\hline 5.6 & B $20.0 \mathrm{~b}$ & $\mathrm{AB} 78.7 \mathrm{a}$ & $49.3 \mathrm{~b}$ \\
\hline 11.2 & B $37.1 \mathrm{a}$ & BB $50.3 \mathrm{a}$ & $43.7 \mathrm{~b}$ \\
\hline 16.8 & B $21.0 \mathrm{~b}$ & $\mathrm{AB} 70.1 \mathrm{a}$ & $45.5 \mathrm{~b}$ \\
\hline 28.0 & B $22.3 \mathrm{~b}$ & $\mathrm{AB} 68.2 \mathrm{a}$ & $45.2 \mathrm{~b}$ \\
\hline $\mathrm{CV}(\%)$ & & & 34.16 \\
\hline
\end{tabular}

Note. ${ }^{1}$ Averages followed by the same letter high case at column and lowercase at line, do not differ by Tukey's test at $5 \%$ of error probability. ${ }^{\mathrm{ns}}$ not significative at level of $5 \%$ of error probability.

At 28 DAT, the negative influences exerted by the dicamba on the soybean plant stature were more noticeable as the subdoses were increased. During the V3 stage, the soybean subdoses applied were $1.4 ; 2.8 ; 5.6 ; 11.2 ; 16.8$ and $28.0 \mathrm{~g}$ ae ha $^{-1}$ induced plant height decrease by $29,29,40,45,44$ and $53 \%$ relative to the control. In the R2 stage, soybean revealed higher tolerance during this evaluation period, where only from the $5.6 \mathrm{~g}$ ae $\mathrm{ha}^{-1}$ subdose, 
the reduction in plant height was evident; however, at the maximum subdose used $\left(28.0 \mathrm{~g}\right.$ ae ha $\left.\mathrm{h}^{-1}\right)$ the reduction was $30 \%$ compared with the control. On measuring the plant height at maturation, the herbicide applied during V3 confirmed its intense negative effect on plant stature. At the lowest subdose $\left(1.4 \mathrm{~g}\right.$ ae ha $\left.{ }^{-1}\right)$ and the highest subdose $\left(28.0 \mathrm{~g} \mathrm{ae} \mathrm{ha}^{-1}\right)$ the plants varied greatly from the control, demonstrating a reduced yield of 60 and $77 \%$, respectively. During the R2, a difference was noted in which the subdoses exerted a lower effect in response to the application at V3. The highest subdose $\left(28.0 \mathrm{~g}_{\text {ae }} \mathrm{ha}^{-1}\right)$ caused $27 \%$ decrease in stature, much lower than that recorded in the V3 stage. This finding is mostly due to the stature of the soybean plants at the time of application; in the R2, the plant growth was practically complete, in contrast to the V3 phase at which the soybean still needed to increase in stature.

\subsection{Yield Components}

The yield components determined included number of nodes, number of branches, thousand seed weight and number of pods. The dicamba herbicide doses affected the number of nodes and number of pods (Table 4, Figure 2). The other yield components showed no statistical difference from the control (without herbicide application).

Table 4. Number of branches (branches plant ${ }^{-1}$ ), thousand seed weight (TSW) (g) e number of pods (pods plant ${ }^{-1}$ ) of soybean, Syngenta 13561 IPRO cultivar, in function of dicamba subdoses and growth stages of soybean. Passo Fundo-RS, 2016

\begin{tabular}{llll}
\hline Dose $\left(\mathrm{g} \mathrm{ae} \mathrm{ha}^{-1}\right)$ & Branches & TSW & Pods \\
\hline 0.0 & $1.51^{\mathrm{ns}}$ & $169.1^{\mathrm{ns}}$ & $44.5^{\mathrm{ns}}$ \\
1.4 & $3.86^{\mathrm{ns}}$ & $176.2^{\mathrm{ns}}$ & $43.4^{\mathrm{ns}}$ \\
2.8 & $2.42^{\mathrm{ns}}$ & $165.7^{\mathrm{ns}}$ & $46.5^{\mathrm{ns}}$ \\
5.6 & $2.87^{\mathrm{ns}}$ & $168.0^{\mathrm{ns}}$ & $46.1^{\mathrm{ns}}$ \\
11.2 & $3.38^{\mathrm{ns}}$ & $163.5^{\mathrm{ns}}$ & $45.0^{\mathrm{ns}}$ \\
16.8 & $3.20^{\mathrm{ns}}$ & $160.0^{\mathrm{ns}}$ & $49.1^{\mathrm{ns}}$ \\
28.0 & $2.61^{\mathrm{ns}}$ & $170.7^{\mathrm{ns}}$ & $44.6^{\mathrm{ns}}$ \\
\hline CV $(\%)$ & $59.13^{\mathrm{ns}}$ & $7.33^{\mathrm{ns}}$ & $20.70^{\mathrm{ns}}$ \\
\hline Growth Stage & Branches & TSW & $51.5 \mathrm{a}^{1}$ \\
\hline V3 & $3.4^{\mathrm{ns}}$ & $171.4^{\mathrm{ns}}$ & $39.7 \mathrm{~b}$ \\
R2 & $2.1^{\mathrm{ns}}$ & $165.5^{\mathrm{ns}}$ & 22.46 \\
\hline CV $(\%)$ & 77.54 & 14.89 & $\mathrm{~m}^{\mathrm{ns}}$ \\
\hline
\end{tabular}

Note. ${ }^{1}$ Averages followed by the same letter high case at column and lowercase at line, do not differ by Tukey's test at $5 \%$ of error probability. ${ }^{\text {ns }}$ not significative at level of $5 \%$ of error probability.

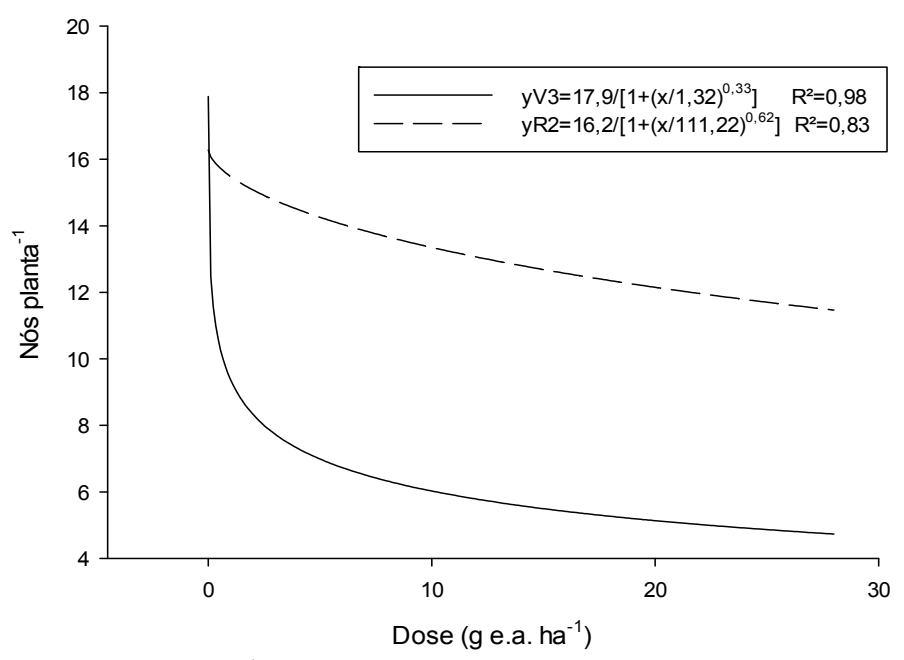

Figure 2. Number of nodes (nodes plant ${ }^{-1}$ ), of soybean, Syngenta 13561 IPRO cultivar, in function of dicamba subdoses and growth stages of soybean. Passo Fundo-RS, 2016 
The number of pods showed statistical significance only for the factor, stage of development. Thus, the dicamba dose applied during the $\mathrm{R} 2$ caused $23 \%$ decrease in the number of pods compared to its application during V3. In light of this, the soybean reveals higher susceptibility to the dicamba doses during the reproductive phase, largely because this factor strongly affects the grain yield. For the variable number of nodes, interactions were observed between the factors tested, with a fit to the logistic-type sigmoidal regression equation model in the two application stages. The values of the coefficient of determination $\left(\mathrm{R}^{2}\right)$ were 0.98 and 0.83 , for the V3 and R2 stages, respectively (Figure 2). The factor, number of nodes, showed the greatest response in the V3 stage from the smallest subdose used $\left(1.4 \mathrm{~g}_{\mathrm{ae} \mathrm{ha}}{ }^{-1}\right)$ and a $71 \%$ decrease in the number of nodes in response to the $28 \mathrm{~g}$ ae $\mathrm{ha}^{-1}$ subdose. During the R2 stage, the number of nodes was affected only from the $18.24 \mathrm{~g}_{\text {ae }} \mathrm{ha}^{-1}$ subdose revealing a $34 \%$ decrease in the number of nodes. Corroborating to these results, the factor, number of pods showed less influence due to the added subdose of $5.9 \mathrm{~g} \mathrm{ae} \mathrm{ha}^{-1}$ of dicamba during the V3 and V7 stages than during the reproductive phase (Kelley et al., 2005).

\subsection{Grain Yield}

The dicamba doses caused the soybean grain yield to drop, through the interaction among the factors investigated. Thus, the data were adjusted to the logistic-type logistic regression model at both the application times, and the coefficient of determination was found in the range of 0.98 to 0.99 for the V3 and R2 phases, respectively (Figure 3). The grain yield in general, decreased by $30 \%$ after the $28.0 \mathrm{~g}$ ae ha ${ }^{-1}$ subdose was applied in the V3 stage, and by 21 and $56 \%$, respectively, after the 16.8 and $28.0 \mathrm{~g}^{2} \mathrm{ae} \mathrm{ha}^{-1}$ were applied during the R2 stage. When the dicamba was applied in the subdoses 4.4 and $17.5 \mathrm{~g}^{2} \mathrm{e} \mathrm{ha}^{-1}$ it induced the grain yield to drop by 4 and $10 \%$ when added during the V3 stage and by 15 and $36 \%$ when added at the R1 stage, respectively (Griffin et al., 2013). Similarly, the dose of $3 \mathrm{~g}$ ae ha ${ }^{-1}$ of dicamba induced a $20 \%$ of decline in grain yield, while the $41 \mathrm{~g}$ ae ha ${ }^{-1}$ subdose reduced it by $85 \%$ when the soybean was at a height of 20-30 cm (Johnson et al., 2012).

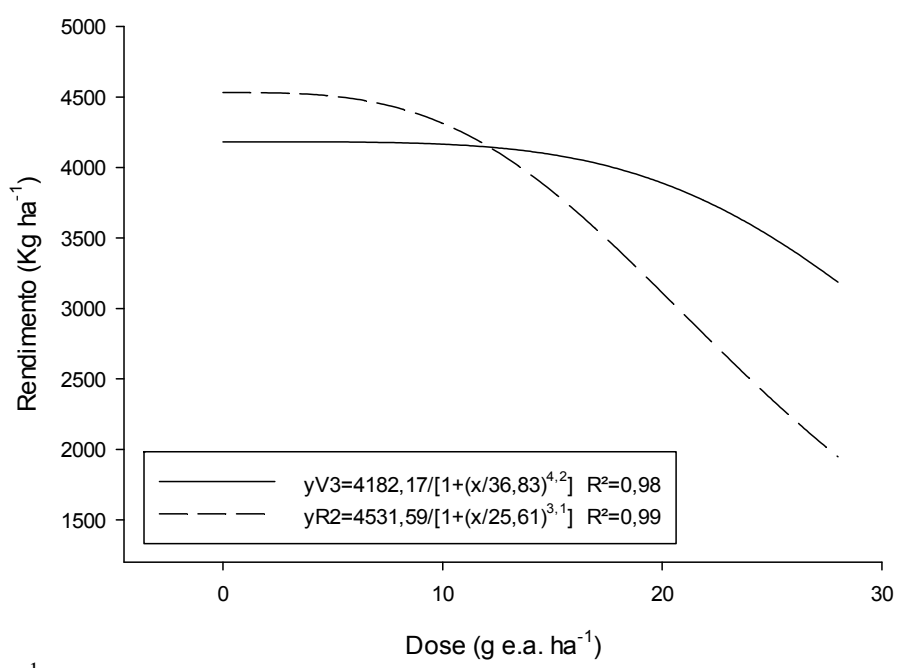

Figure 3. Yield $\left(\mathrm{kg} \mathrm{ha}^{-1}\right)$, of soybean, Syngenta 13561 IPRO cultivar, in function of dicamba subdoses and growth stages of soybean. Passo Fundo-RS, 2016

Furthermore, when compared with the control, the yield decrease was noted to be in the order of 1, 5, 10, 20 and $50 \%$ with the application of $1.1 ; 5.8 ; 11.8 ; 25.2$ and $60 \mathrm{~g}$ ae ha ${ }^{-1}$, respectively; it was 1 when the dose was applied during the V3 phase and $0.75 ; 1.0 ; 2.0 ; 4.3$ and $11.5 \mathrm{~g}$ ae $\mathrm{ha}^{-1}$ when applied at the R1, respectively, with the grain yield becoming less in response to the increase in the dicamba subdose (Soltani et al., 2016).

This study helps to confirm that the dicamba subdose induced greater damage during the reproductive stage, when the ability of the plant to recover is very low. Tank residues present in the ratio of $16.8 \mathrm{~g}$ ae ha ${ }^{-1}$, corresponding to $3 \%$ of the commercial dose used in this work (represented by $537 \mathrm{~g} \mathrm{ae} \mathrm{ha}^{-1}$ ), caused injurious to the soybean cultivation, producing high phytotoxicity levels and affecting the plants by inducing a decrease in the plant height and number of the plant nodes, which justifies the lowered grain yield in the crop, particularly at the R2 stage. Another point of interest is the pluviometric index observed during the crop cycle (Figure 1). As the rainfall throughout the study period was above average, this was a positive indicator for the crop from the perspective of data recovery and herbicide metabolism (Shaner, 2014). 
As the visual method of assessing phytotoxicity may be subjective to the extent of becoming a variable due to the differences in the human indices, this technique is often not very reliable. Thus, a more thorough evaluation, despite being rather slow, is preferable. Therefore, counting and evaluating the components of yield can raise the accuracy of the results and indicate the starting point at which the crop yield begins to respond to the herbicide and show decrease. Several other cultures show similar sensitivity to the drift or dicamba residues, like vines, smoke, tomato (Constantin et al., 2007; Oliveira Jr., 2007).

\section{Conclusions}

In conclusion, the dicamba residues from $5 \%$ of the commercial dose at stage V3 and, from $3 \%$ at stage R2, cause the soybean yield to decrease. Therefore, the spray tanks need to be thoroughly cleaned before applying these herbicides to soy products that do not tolerate them.

\section{References}

Andersen, S. A., Clay, S. A., Wrage, L. J., \& Matthees, D. (2004). Soybean foliage residues of dicamba and 2,4-D and correlation to application rates and yield. Agronomy Journal, 96, 750-760. https://doi.org/ 10.2134/agronj2004.0750

Behrens, M. R., Mutlu, N., Chakraborty, S., Dumitru, R., Jiang, W. Z., Lavallee, B. J., ... Weeks, D. P. (2007). Dicamba resistance: Enlarging and preserving biotechnology-based weed management strategies. Science, 316, 1185-1188. https://doi.org/10.1126/science.1141596

Constantin, J., Oliveira Júnior, R. S. de., Fagliari, J. R., Pagliari, P. H., Arantes, J. G. Z., Cavalieri, S. D., ... Gonçalves, D. A. (2007). Effect of 2,4-D subdoses on cotton yield and crop susceptibility as a function of their stage of development. Engenharia Agricola, 27, 24-29. https://doi.org/10.1590/S0100-6916200700 0200004

Embrapa (Empresa Brasileira de Pesquisa Agropecuária). (2006). Sistema Brasileiro de Classificação de Solos (2nd ed., p. 412). Rio de Janeiro: Embrapa SPI.

Embrapa (Empresa Brasileira de Pesquisa Agropecuária). (2016). Normais Climatológicas (1961/1990). Passo Fundo-RS. Retrieved from http://www.cnpt.embrapa.br/pesquisa/agromet/app/principal/normais.php

Frans, R., Talbert, R., Marx, D., \& Crowley, H. (1986). Experimental design and techniques for measuring and analyzing plant responses to weed control practices. In N. D. Camper (Ed.), Research methods in weed science (3rd ed., p. 37). Champaign: Southern Weed Science Society.

Green, J. M., \& Castle, L. A. (2010). Transitioning from single to multiple herbicide-resistant crops. In V. K. Nandula (Ed.), Glyphosate resistance in crops and weeds: History, development, and management (p. 91). Wiley, Hoboken, NJ. https://doi.org/10.1002/9780470634394.ch4

Griffin, J. L., Bauerle, M. J., Stephenson, D. O., Miller, D. K., \& Boudreaux, M. (2013). Soybean response to dicamba applied at vegetative and reproductive growth stages. Weed Technology, 27, 696-703. https://doi.org/10.1614/WT-D-13-00084.1

Grossmann, K. (2010). Auxin herbicides: Current status of mechanism and mode of action. Pest Management Science, 66, 113-120.

Johnson, V. A., Fisher, L. R., Jordan, D. L., Edmisten, K. E., Stewart, A. M., \& York, A. C. (2012). Cotton, peanut, and soybean response to sublethal rates of dicamba, glufosinate, and 2,4-D. Weed Technology, 26, 195-206. https://doi.org/10.1614/WT-D-11-00054.1

Kelley, K. B., Lambert, K. N., Hager, A. G., \& Riechers, D. G. (2004). Quantitative expression analysis of GH3, a gene induced by plant growth regulator herbicides in soybean. Journal of Agriculture, Food and Chemistry, 52, 474-478. https://doi.org/10.1021/jf0351341

Kelley, K. B., Wax, L. M., Hager, A. G., \& Riechers, D. E. (2005). Soybean response to plant growth regulator herbicides is affected by other post emergence herbicides. Weed Science, 53, 101-112. https://doi.org/ 10.1614/WS-04-078R

Oliveira Júnior, R. S., Constantin, J., Brandão, J. U. T., Cavalieri, S. D., Framesqui, V. P., Carreira, S. A. M., \& Roso, A. C. (2007). Effect of 2,4-D sub-doses on grape yield in Italy and susceptibility of the crop to its stage of development. Engenharia Agricola, 27, 35-40. https://doi.org/10.1590/S0100-69162007000200006

Olszyk, D., Pfleeger, T., Lee, E. H., \& Plocher, M. (2015). Glyphosate and dicamba herbicide tank mixture effects on native plant and non-genetically engineered soybean seedlings. Ecotoxicology, 24, 1014-1027. https://doi.org/10.1007/s10646-015-1442-8 
Robinson, A. P., Davis, V. M., Simpson, D. M., \& Johnson, W. G. (2013). Response of Soybean Yield Components to 2,4-D. Weed Science, 61, 68-76. https://doi.org/10.1614/WS-D-12-00077.1

Shaner, D. L. (2014). Herbicide handbook (10th ed., p. 513). Weed Science Society of America, Champaign, IL.

Sigmaplot. (2007). Scientific Graphing Software (Version 10.0).

Soltani, N., Nurse, R. E., \& Sikkema, P. H. (2016). Response of glyphosate-resistant soybean to dicamba spray tank contamination during vegetative and reproductive growth stages. Canadian Journal of Plant Science, 96, 160-164. https://doi.org/10.1139/cjps-2015-0175

Vink, J. P., Soltani, N., Robinson, D. E., Tardif, F. J., Lawton, M. B., \& Sikkema, P. H. (2012). Glyphosate-resistant giant ragweed (Ambrosia trifida) control in dicamba-tolerant soybean. Weed Technology, 26, 422-428. https://doi.org/10.1614/WT-D-11-00184.1

\section{Copyrights}

Copyright for this article is retained by the author(s), with first publication rights granted to the journal.

This is an open-access article distributed under the terms and conditions of the Creative Commons Attribution license (http://creativecommons.org/licenses/by/4.0/). 